\title{
THIN FILMS DEPOSITED BY SPIN COATING TECHNIQUE: REVIEW
}

\author{
H. Soonmin \\ INTI International University, \\ Putra Nilai, 71800, Negeri Sembilan, MALAYSIA. \\ *Corresponding author email: soonmin.ho@newinti.edu.my
}

\begin{abstract}
:
Nanostructure thin films have been prepared and deposited onto various substrates such as glass substrate, quartz, GaN (0001) substrate, indium tin oxide coated glass, soda-lime glass, microscope glass slide via spin coating technique. This deposition method has many advantages, such as being cheap, simple, suitable for the low-temperature deposition process. Literature review revealed that the deposition process was carried out at different conditions produced unique properties of films. Structural, morphological, and optical properties were studied by X-ray diffraction, scanning electron microscopy, atomic force microscopy, and UV-Visible spectrophotometer. It was found that the average grain size of the obtained films was in the nanometer scale. The research findings confirmed that these materials could be used for photovoltaic applications.
\end{abstract}

Keywords: spin coating technique, substrate, thin films, photovoltaic applications

\section{INTRODUCTION}

The thin film's development for energy conversion and optoelectronic materials, among other applications, is of great interest $[1,2]$. Because of the low cost, non-toxic starting materials indicate excellent electrical, photovoltaic, photo catalytically and optical properties [3-6]. Nowadays, there is an extended interest in researching different synthesis methodologies for metal chalcogenide thin films, such as metal selenide, metal sulfide, and metal telluride thin films. Several synthesis methodologies for these materials have been reported including spray pyrolysis [7,8], electrodeposition $[9,10]$, thermal evaporation $[11,12]$, chemical bath deposition [13,14], successive ionic layer adsorption and reaction [15,16], atomic layer deposition [17], molecular beam epitaxy [18], pulsed laser deposition [19], and sol-gel method [20]. Researchers conclude that each methodology has advantages and disadvantages [21-24]. Among the main disadvantages are high cost, toxicity, elevated synthesis temperatures, a considerable number of byproducts, annealing requirements at high temperatures after synthesis that limit the use of flexible substrates, and films heterogeneity. Several instruments including atomic force microscopy (AFM), Rutherford backscattering spectrometry (RBS), X-ray diffraction (XRD), scanning electron microscopy (SEM), energy dispersive X-ray analysis (EDAX), scanning tunneling microscopy [25,26], Raman spectrometry, real-time reflection high energy electron diffraction [27,28], UV-Visible spectrophotometer (UV-Visible) are used to investigate general properties of films.

This work presented a review of the preparation of thin films using a spin coating technique. This method was chosen for simplicity, low cost, low by-product formation, low temperature, and no-annealing requirements. Structural, electrical, optical, and morphological properties of the prepared thin films were discussed.

The deposition technique could be divided into chemical deposition technique and physical deposition method. Generally, a higher operational cost is needed to synthesize thin films using the physical method (Figure 1). Thin films have been prepared by using various deposition methods, as highlighted by many researchers. Metal selenide, metal sulphide, and metal telluride thin films were reported as listed in Table (1-3). Characterization of obtained films was carried out by using various tools.

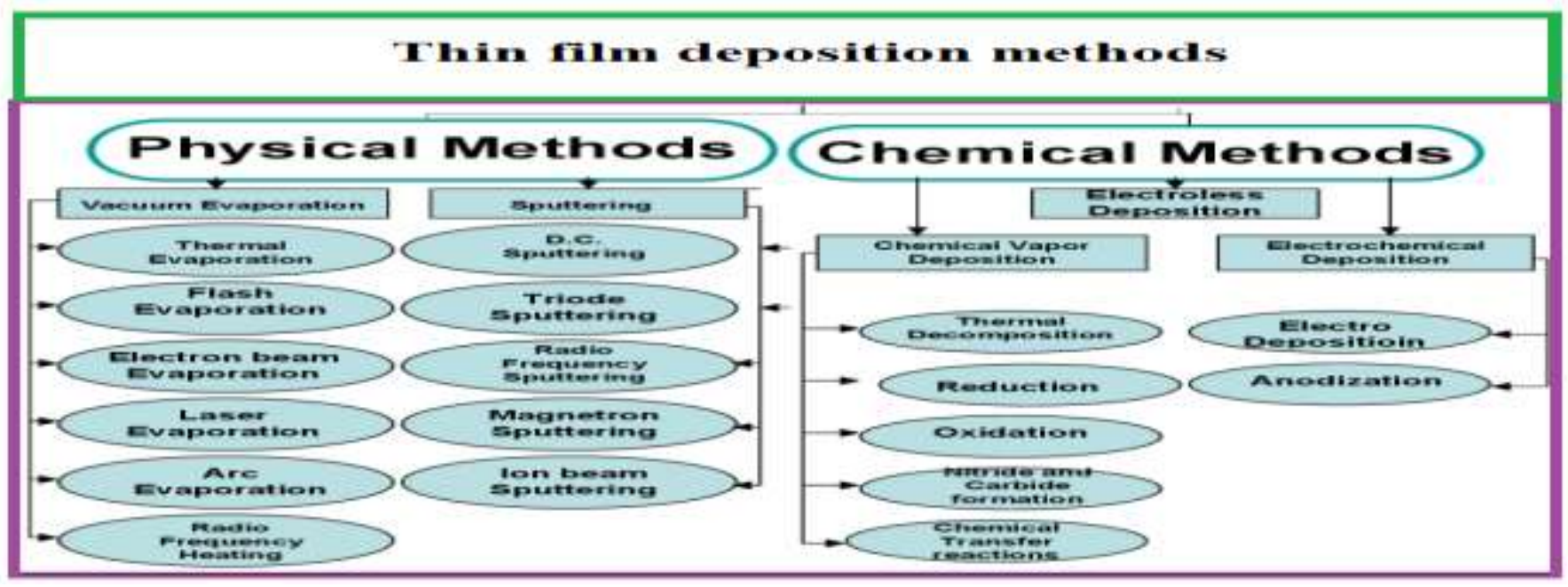


Fig. 1: Thin film deposition methods [29]

Table 1: Metal selenide thin films have been prepared under various deposition methods

\begin{tabular}{|c|c|c|}
\hline $\begin{array}{l}\text { Thin } \\
\text { films }\end{array}$ & $\begin{array}{c}\text { Deposition } \\
\text { method }\end{array}$ & Experimental results \\
\hline $\mathrm{ZnSe}$ & $\begin{array}{l}\text { Chemical bath } \\
\text { deposition }\end{array}$ & $\begin{array}{l}\text { - AFM: uniform grain size and complete coverage over the substrate } \\
\text { for the films prepared at } \mathrm{pH} 2[30] \text {. }\end{array}$ \\
\hline $\mathrm{CdSe}$ & $\begin{array}{l}\text { Chemical bath } \\
\text { deposition }\end{array}$ & $\begin{array}{l}\text { - } \mathrm{RBS}=\text { excess of cadmium rather than selenium [31]. } \\
\text { - UV-Visible: bandgap ( } 3.52 \text { to } 1.86 \mathrm{eV}) \text {. } \\
\text { - XRD: cubic structure. } \\
\text { - SEM: diameter of } 33 \mathrm{~nm} \text { and } 40 \mathrm{~nm} \text { for the films prepared at } 40 \text { and } \\
50{ }^{\circ} \mathrm{C} \text {. }\end{array}$ \\
\hline $\mathrm{NiSe}$ & $\begin{array}{l}\text { Chemical bath } \\
\text { deposition }\end{array}$ & $\begin{array}{l}\text { - XRD: rhombohedral structural. } \\
\text { - AFM: covered the surface of the substrate and irregularly shaped } \\
\text { grains [32]. } \\
\text { - UV-Visible: bandgap }(1.8 \mathrm{eV}) \text {. }\end{array}$ \\
\hline $\mathrm{PbSe}$ & $\begin{array}{l}\text { Chemical bath } \\
\text { deposition }\end{array}$ & $\begin{array}{l}\text { - XRD: cubic with the most preferential peak corresponded to (111) } \\
\text { plane. } \\
\text { - UV-Visible: Bandgap reduced from } 2 \text { to } 1.3 \mathrm{eV} \text { as bath temperature } \\
\text { was increased [33]. }\end{array}$ \\
\hline $\mathrm{ZnSe}$ & $\begin{array}{l}\text { Thermal } \\
\text { evaporation }\end{array}$ & $\begin{array}{l}\text { - XRD: cubic phase and the highest peak corresponded to (111) } \\
\text { plane [34]. } \\
\text { - AFM: Smooth surface and roughness }(6.7 \mathrm{~nm}) \text {. } \\
\text { - UV-Visible: Bandgap of } 2.7 \mathrm{eV} \text { and high transmission }(89 \%) \text { in the } \\
\text { infrared region. }\end{array}$ \\
\hline
\end{tabular}

Table 2: Metal sulphide thin films have been prepared under various deposition methods

\begin{tabular}{|c|c|c|}
\hline Thin films & $\begin{array}{l}\text { Deposition } \\
\text { method }\end{array}$ & Experimental results \\
\hline $\mathrm{CuS}$ & $\begin{array}{l}\text { Chemical bath } \\
\text { deposition }\end{array}$ & $\begin{array}{l}\text { - AFM: incomplete coverage of the materials over the surface of a } \\
\text { substrate for the films prepared at one hour [35]. }\end{array}$ \\
\hline $\mathrm{Cu}_{4} \mathrm{SnS}_{4}$ & $\begin{array}{l}\text { Electro } \\
\text { deposition }\end{array}$ & $\begin{array}{l}\text { - XRD: orthorhombic structure [36]. } \\
\text { - AFM: small grain and uniform surface for the films prepared at } 25^{\circ} \mathrm{C} \text { for } \\
45 \text { minutes. } \\
\text { - UV-Visible: } 1.68 \mathrm{eV} \text {. }\end{array}$ \\
\hline $\mathrm{Ni}_{3} \mathrm{~Pb}_{2} \mathrm{~S}_{2}$ & $\begin{array}{l}\text { Chemical bath } \\
\text { deposition }\end{array}$ & $\begin{array}{l}\text { - SEM: homogeneous and regular surface for the films prepared at } 1 \text { hour } \\
\text { [37]. }\end{array}$ \\
\hline $\mathrm{SnS}$ & $\begin{array}{l}\text { Chemical bath } \\
\text { deposition }\end{array}$ & $\begin{array}{l}\text { - XRD: The strongest peak at } 2 \theta=31.69^{\circ} \text {. } \\
\text { - SEM: non-uniform surface and grain sizes }(10-25 \mathrm{~nm}) \text { [38]. }\end{array}$ \\
\hline $\mathrm{Ni}_{4} \mathrm{~S}_{3}$ & $\begin{array}{l}\text { Chemical bath } \\
\text { deposition }\end{array}$ & $\begin{array}{l}\text { - XRD: cubic structure. } \\
\text { - UV-Visible: } 0.85 \text { to } 1.8 \mathrm{eV} \text { depending on the } \mathrm{pH}[39] .\end{array}$ \\
\hline $\mathrm{CdS}, \mathrm{CuS}, \mathrm{ZnS}$ & SILAR & $\begin{array}{ll}\text { - } & \text { XRD: CdS (hexagonal), CuS (covellite), ZnS (cubic). } \\
\text { - } & \text { SEM: homogeneous and covered the substrate well [40]. }\end{array}$ \\
\hline
\end{tabular}




\begin{tabular}{|c|c|c|}
\hline $\mathrm{FeS}_{2}$ & $\begin{array}{l}\text { Chemical bath } \\
\text { deposition }\end{array}$ & $\begin{array}{l}\text { XRD: strong peak corresponded to (110) plane [41]. } \\
\text { - SEM: Irregular grains. } \\
\text { - UV-Visible: band gap of } 1.85 \mathrm{eV} \text {. }\end{array}$ \\
\hline $\mathrm{PbS}$ & SILAR & $\begin{array}{l}\text { - XRD: prominent peak was corresponded to (200) plane [42]. } \\
\text { - AFM: film thickness }(20-30 \mathrm{~nm}) \text {. }\end{array}$ \\
\hline $\mathrm{ZnS}$ & $\begin{array}{l}\text { RF magnetron } \\
\text { sputtering }\end{array}$ & $\begin{array}{l}\text { - SEM: grain size }(69 \mathrm{~nm}) . \\
\text { - } \quad \text { UV-Visible: bandgap of } 3.79 \mathrm{eV} \text {. } \\
\text { - XRD: show (111) plane and indicate zinc blende structure [43]. }\end{array}$ \\
\hline $\mathrm{PbS}$ & $\begin{array}{l}\text { Chemical bath } \\
\text { deposition }\end{array}$ & $\begin{array}{l}\text { - } \quad \text { SEM: non-uniform and dense [44]. } \\
\text { - } \quad \text { EDAX: atomic percentage of } \mathrm{Pb}: \mathrm{S} \text { was } 49.18: 50.82 \% \text {. }\end{array}$ \\
\hline $\mathrm{ZnS}$ & $\begin{array}{l}\text { Thermal } \\
\text { evaporation }\end{array}$ & $\begin{array}{l}\text { - XRD: cubic zinc blend structure with (111) preferential plane [45]. } \\
\text { - UV-Visible: bandgap of } 3.5 \mathrm{eV} \text {. } \\
\text { - SEM: the films are pinhole-free. }\end{array}$ \\
\hline $\mathrm{FeS}$ & $\begin{array}{l}\text { Chemical bath } \\
\text { deposition }\end{array}$ & $\begin{array}{l}\text { - XRD: Thin films prepared using } 0.1 \mathrm{M}, 0.15 \mathrm{M} \text { and } 0.2 \mathrm{M} \text { of solution } \\
\text { concentration indicated } 3,4 \text {, and } 5 \text { peaks, respectively [46]. } \\
\text { - SEM: the films prepared using } 0.2 \mathrm{M} \text { covered the entire surface of the } \\
\text { substrate. }\end{array}$ \\
\hline
\end{tabular}

Table 3: Metal telluride thin films have been prepared under various deposition methods

\begin{tabular}{|c|c|c|}
\hline Thin films & $\begin{array}{c}\text { Deposition } \\
\text { method }\end{array}$ & Experimental results \\
\hline ZnTe & SILAR & $\begin{array}{l}\text { - EDAX: Zn:Te was 53:47. } \\
\text { - SEM: densely aggregated particles (in } \mathrm{nm} \text { ) without voids [47]. }\end{array}$ \\
\hline CdTe & $\begin{array}{l}\text { RF magnetron } \\
\text { sputtering }\end{array}$ & $\begin{array}{l}\text { - XRD: strong (111) orientation and cubic structure [48]. } \\
\text { - UV-Visible: band gap values (1.44 to } 1.6 \mathrm{eV} \text { ). }\end{array}$ \\
\hline $\mathrm{Bi}_{2} \mathrm{Te}_{3}$ & $\begin{array}{l}\text { Thermal co- } \\
\text { evaporation }\end{array}$ & - XRD: strong (105) orientation and rhombohedral structure [49]. \\
\hline SnTe & $\begin{array}{l}\text { Molecular beam } \\
\text { epitaxy }\end{array}$ & $\begin{array}{l}\text { - STM: tetragonal structure. } \\
\text { - } \text { RHEED: formation of flat films [50]. }\end{array}$ \\
\hline $\mathrm{CdTe}$ & Electrodeposition & $\begin{array}{l}\text { - XRD: prominent peak was observed at (111) plane [51]. } \\
\text { - Raman: Peak at } 140 \mathrm{~cm}^{-1} \text { indicated CdTe fingerprint. }\end{array}$ \\
\hline
\end{tabular}

Spin coating is employed in a wide variety of industries, semiconductor and nanotechnology sectors. It offers several advantages, including easy to set-up, require low temperature for deposition process [52], it does not limit the choice of the substrate material [53], low-cost, simple form uniform and homogeneous [54] thin films (in nanoscale thickness) [55] onto the flat substrate and produce well-defined coating coverage. It employs centrifugal forces created by a spinning substrate to spread a coating solution evenly over the substrate. During the deposition process, solid particles are dissolved in a solvent. The mixture is spin-coated on the surface of the substrate. The process produces a gelatinous network on the substrate. Subsequent solvent removal solidifies the gel [56], resulting in solid film [57]. Film thickness will depend on the nature of coating [58] and the conditions [59] chosen for the spin process, such as rotation speed 
[60], viscosity, and concentration of the solution. The solvent evaporates during the spin coating process and causes an increasing concentration and viscosity [61]. The more concentrated the solution, the thicker films could be produced. The stages of the deposition of the thin films by the spin coating method are shown in Figure (2) reported by Marek and Dobrzanski [62].

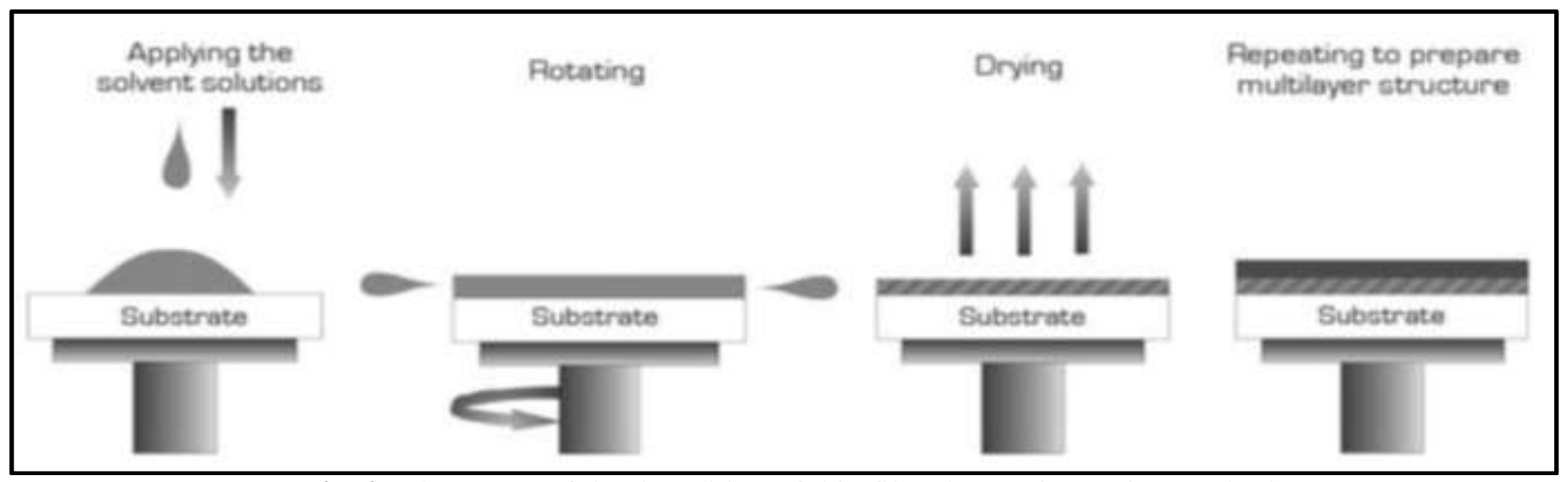

Fig. 2: The stages of the deposition of thin films by a spin coating method

The $\mathrm{Cu}_{2} \mathrm{Zn}_{0.8} \mathrm{Cd}_{0.2} \mathrm{SnS}_{4}$ films were synthesized using the spin coating method onto glass substrate [63]. The solution of copper (II) chloride monohydrate, zinc (II) acetate dihydrate, tin (II) chloride dihydrate, cadmium (II) chloride, thiourea, monoethanolamine, and 2-methoxyethanol was used during the deposition process. XRD patterns confirm that the presence of $\mathrm{ZnS}, \mathrm{SnS}, \mathrm{Cu}_{2} \mathrm{~S}$, and CZTS in obtained samples. Larger grain sizes (35 to $68 \mathrm{~nm}$ ) and the intensity of peaks become more intense, with increasing copper concentration from 0.3 to $0.9 \mathrm{M}$. In other words, they found that bigger grain size brings an advantage in improving photovoltaic performance. EDAX spectra reveal that the films were copper-rich and tin-rich, while SEM studies indicate the spherical grains with voids for the films prepared at high concentrations of copper solution $(0.7$ and $0.9 \mathrm{M})$. Optical properties reveal that all the samples have an absorption coefficient of more than $10^{4} \mathrm{~cm}^{-1}$, and the bandgap value reduces $(1.8$ to $1.6 \mathrm{eV})$ with an increase in copper concentration.

$\mathrm{Cu}_{2} \mathrm{CdSnS}_{4}$ (CCTS) thin films have been prepared on $\mathrm{GaN}$ (0001) substrate using spin-coating technique under different spin coating speeds [64]. The optical properties indicate the changing of bandgap as the spin coating speed increases from $1500(2.7 \mathrm{eV}), 2000(2.55 \mathrm{eV}), 2500(2.4 \mathrm{eV}), 3000(2.5 \mathrm{eV})$ to $3500(2.6 \mathrm{eV}) \mathrm{rpm}$. Structural properties displayed that nine and ten peaks could be observed for the films prepared at 1500 and $3500 \mathrm{rpm}$, respectively and confirmed tetragonal stannite structure. However, these peaks have less intensity if compared to other speeds. It is worth noting that the morphology was the best at $3500 \mathrm{rpm}$, enhancing the characteristics of films for optoelectronic application. The surface roughness and the depth of films were $23.6 \mathrm{~nm}$ and $70.21 \mathrm{~nm}$, respectively. On the other hand, copper nitrate hexahydrate, cadmium nitrate tetrahydrate, tin chloride dihydrate, thiourea, 2-methoxyethanol, and 1,2dichlorobenzene were used to deposit $\mathrm{Cu}_{2} \mathrm{CdSnS}_{4}$ (CCTS) films onto ITO glass substrate [65]. Spin-coated CCTS films show a weak diffraction peak, have an average grain diameter of $8.52 \mathrm{~nm}$ and exhibit a strong peak corresponding to (112) plane. HRTEM image confirmed the nanocrystalline nature of films and tetragonal structure. They notice that the power conversion efficiency of CCTS films (having thickness of $90 \mathrm{~nm}$ ) is higher $(3.63 \%)$ if compared to other samples (2.41-3.51\%). Because of compactness and uniform surface, it produced optimum interface and improved the charge transfer dynamics.

The $\mathrm{Cu}_{2} \mathrm{SnS}_{3}$ (CTS) films were deposited on glass substrate using the spin coating [66]. Copper (II) acetate monohydrate, tin (II) chloride, thiourea, 2-methoxyethanol, Triton-X-100 (resulted in smoother and continuous texture), and diethanolamine were used during the deposition process. Tetragonal structure with the major peak corresponded to (112) plane based on XRD data. Crystallite size increased (17 to $23 \mathrm{~nm})$ whereas microstrain $\left(2.2 \times 10^{-3}\right.$ to $\left.1.6 \times 10^{-3}\right)$, dislocation density $\left(2.6 \times 10^{15}\right.$ to $\left.1.8 \times 10^{15} \mathrm{~m}^{-2}\right)$ reduced with increasing Triton-X-100 content ( 1 to $\left.3 \%\right)$. Morphology study was performed using the atomic force microscopy (AFM) tool. Spin-coated films were rough compact without holes, indicating they are suitable to avoid shunting problems in solar cells [67]. A bigger grain size could be observed, reducing recombination at grain boundaries and involving carrier transport within the grain. Ideal band gap values (1.19 to $1.65 \mathrm{eV}$ ) and the observed light sensibility cause these materials to be a promising candidate for solar cell application. Raman spectra were used to analyze the composition of films. Two peaks ( 289 and $352 \mathrm{~cm}^{-1}$ ) were detected, representing the vibration symmetry of CTS films. XPS was used to study the film's chemistry nature. The obtained results show Cu $2 \mathrm{p}^{1 / 2}, 2 \mathrm{p}^{3 / 2}, \mathrm{Sn} 3 \mathrm{~d}^{3 / 2}, 3 \mathrm{~d}^{5 / 2}, \mathrm{~S} 2 \mathrm{p}^{1 / 2}$ and $\mathrm{S} 2 \mathrm{p}^{3 / 2}$. Hall effect measurement was carried out, and results show p-type semiconductor material (Hall coefficient $=1.3 \mathrm{~cm}^{3} / \mathrm{C}$ ). Lastly, the CTS was used as the absorber material to check photovoltaic device performance [68]. It reached a solar conversion efficiency of $0.78 \%$ with a fill factor $(27.4 \%)$. 
Acetic acid, ethanol, polyethylene glycol, thiourea, and cadmium nitrate were employed to grow CdS films onto glass substrate at various annealed temperatures [69]. XRD studies found that more diffraction peaks (four peaks) and better polycrystalline could be detected at $2200 \mathrm{rpm}, 400{ }^{\circ} \mathrm{C}$. The direct bandgap $(3.03,2.88$, and $2.75 \mathrm{eV})$ reduces with increasing temperature from 200 to $400{ }^{\circ} \mathrm{C}$, indicating a quantum confinement effect. High-resolution transmission electron microscopy results indicate lattice fringes representing the formation of good nanocrystalline in the annealed films $\left(150{ }^{\circ} \mathrm{C}\right)$. Further, they conclude that d-spacing of $0.357 \mathrm{~nm}$ corresponded to (100) reflection of hexagonal structure and grain size of $5 \mathrm{~nm}$. Atomic force microscopy images show small grains, homogeneous, without voids, and the roughness of $37 \mathrm{~nm}$ [70]. The photoluminescence (PL) emission spectra exhibit two peaks at 486 (green emission) and $542 \mathrm{~nm}$ (yellow band). The influence of spin coating speed on the properties of CdS was studied. The observed sharp peak at $5000 \mathrm{rpm}$, shows the presence of good crystalline and is suitable for photocatalytic reaction. The grain size increases with an increase in spin coating speed based on the calculation of the Scherrer formula (from 1.4 to 6.3 $\mathrm{nm}$ ) and SEM images [71]. The studies of transmittance spectra show 40-50\% and 80\% transmission at 1000 and 5000 rpm, respectively.

In the past few years, there have been several reports on the properties of thin films prepared using the spin coating method, as shown in Table 4. Investigation into the material properties by using various tools was performed. The main disadvantage of this technique is its lack of material efficiency. The actual material used is about ten percentages, the rest being flung off the side. The fast drying times can also cause lower performance for some particular nanotechnology.

Table 4: Thin films prepared using spin coating technique.

\begin{tabular}{|c|c|c|}
\hline Thin films & Experimental conditions & Highlighted results \\
\hline $\begin{array}{l}\text { Copper } \\
\text { doped ZnS }\end{array}$ & $\begin{array}{l}\text { Synthesis of copper doped } \mathrm{ZnS} \\
\text { films on filter paper (as flexible } \\
\text { substrate) in the presence of zinc } \\
\text { chloride and thiourea. }\end{array}$ & $\begin{array}{l}\text { - SEM studies: indicate fibrous morphology [72]. } \\
\text { - XRD studies: cubic structure } \\
\text { - The obtained films show excellent } \\
\text { photoluminescence properties and conductivity } \\
\text { value }\left(3.07 \text { to } 4.3 \times 10^{6} \Omega^{-1} \mathrm{~cm}^{-1}\right) \text {. }\end{array}$ \\
\hline $\mathrm{ZnS}$ & $\begin{array}{l}\text { - ZnS films were prepared on a } \\
\text { glass substrate. } \\
\text { - Zinc sulfate and } \\
\text { polymethylmethacrylate were } \\
\text { used during the deposition } \\
\text { process. }\end{array}$ & $\begin{array}{l}\text { - SEM studies: Semispherical morphology [73]. } \\
\text { - XRD studies: the most preferential peak } \\
\text { corresponded to (111) plane, and crystallite size } \\
\text { was } 35 \mathrm{~nm} \text {. } \\
\text { - Optical properties: bandgap was } 4.12 \mathrm{eV} \text {, and } \\
\text { absorbance in the ultraviolet region is high. }\end{array}$ \\
\hline $\mathrm{ZnS}$ & $\begin{array}{llr}\text { - } & \text { Preparation of zinc } & \text { sulphide } \\
\text { films } & \text { by } & \text { adding } \\
\text { dimethylsulphoxide. } & \end{array}$ & $\begin{array}{l}\text { - XRD studies: hexagonal structure and } \\
\text { polycrystalline in nature [74]. } \\
\text { - EDAX studies: nearly stoichiometric films. } \\
\text { - SEM studies: smooth and uniform grains (20-25 } \\
\text { nm). } \\
\text { - Optical properties: high transmittance in the } \\
\text { visible region, and bandgap was } 3.6 \mathrm{eV} \text {. }\end{array}$ \\
\hline $\mathrm{ZnS}$ & $\begin{array}{l}\text { ZnS films were grown on quartz } \\
\text { substrate, and the raw materials } \\
\text { were zinc nitrate and thiourea. }\end{array}$ & $\begin{array}{l}\text { - XRD studies: hexagonal wurtzite structure and } \\
\text { the major peak was (100) plane [75]. } \\
\text { - SEM studies: formation of sub-micrometer } \\
\text { grains on the surface. } \\
\text { - Optical properties: bandgap was } 3.7 \mathrm{eV} \text {. }\end{array}$ \\
\hline
\end{tabular}




\begin{tabular}{|c|c|c|}
\hline$\overline{\mathrm{CdS}}$ & $\begin{array}{l}\text { - Cupric acetate, thiourea and } \\
\text { cadmium acetate as starting } \\
\text { materials. } \\
\text { - Copper ions were added to CdS } \\
\text { films at various spin speeds and } \\
\text { times. }\end{array}$ & $\begin{array}{l}\text { - XRD studies: addition of a small amount of } \\
\text { copper ions did not change the structure [76]. } \\
\text { - Optical properties: Bandgap reduces (2.45 to } \\
2.18 \mathrm{eV}) \text { with the percentage of copper ions } \\
\text { from } 0.1 \text { to } 0.6 \% \text {. } \\
\text { - Photovoltaic properties: Fill factor }(19.69 \text { to } \\
49.21 \%) \text {, efficiency }(0.09 \text { to } 0.86 \%) \text { and } \\
\text { photocurrent density }\left(0.013 \text { to } 0.046 \mathrm{~mA} . \mathrm{cm}^{-2}\right) \\
\text { increase with the percentage of copper ions from } \\
0.1 \text { to } 0.6 \% \text {. }\end{array}$ \\
\hline $\mathrm{CuInSe}_{2}$ & $\begin{array}{l}\text { - } \mathrm{CuInSe}_{2} \text { films were grown on a } \\
\text { quartz substrate. }\end{array}$ & $\begin{array}{l}\text { - EDAX studies: the films prepared nitrogen } \\
\text { atmosphere show a deficiency of selenium. The } \\
\text { ratio of } \mathrm{Se}:(\mathrm{Cu}+\mathrm{In})=0.55 \text {. } \\
\text { - XRD studies: improvement of crystallinity } \\
\text { under appropriate sintering time and the } \\
\text { sintering selenium vapour [77]. }\end{array}$ \\
\hline $\mathrm{SnS}_{2}$ & $\begin{array}{l}\text { - The growth of } \mathrm{SnS}_{2} \text { films at } \\
\text { room temperature. }\end{array}$ & $\begin{array}{l}\text { - XRD studies: hexagonal structure and the } \\
\text { crystallite size was obtained }(9.7,6.5 \mathrm{~nm}) \text {. } \\
\text { - EDAX studies: near stoichiometric films [78]. } \\
\text { - SEM studies: flat, uniform morphology and free } \\
\text { cracking. } \\
\text { - Optical properties: band gap increases with } \\
\text { reduce in film thickness }\end{array}$ \\
\hline $\mathrm{PbS}$ & $\begin{array}{l}\text { - PbS films were prepared on glass } \\
\text { substrate. }\end{array}$ & $\begin{array}{l}\text { - XRD studies: good crystalline cubic structure } \\
\text { [79]. } \\
\text { - } \quad \text { SEM studies: homogeneous surface. } \\
\text { - Optical properties: Direct band gap was } 0.41 \mathrm{eV} \\
\text { and high absorption coefficient }\left(10^{4} \mathrm{~cm}^{-1}\right) .\end{array}$ \\
\hline $\mathrm{Cu}_{2} \mathrm{SnS}_{3}$ & $\begin{array}{l}\text { - Synthesis of } \mathrm{Cu}_{2} \mathrm{SnS}_{3} \text { by using } \\
\text { polyethylene glycol (PEG). }\end{array}$ & $\begin{array}{l}\text { - XRD studies: polycrystalline in nature [80]. } \\
\text { - SEM studies: dense, agglomeration like } \\
\text { morphology. } \\
\text { - Optical properties: Band gap increased with } \\
\text { decreasing the PEG content. }\end{array}$ \\
\hline $\mathrm{Cu}_{2} \mathrm{ZnSnS}_{4}$ & $\begin{array}{l}\text { - } \mathrm{Cu}_{2} \mathrm{ZnSnS}_{4} \text { films were produced } \\
\text { by using copper (II) chloride, } \\
\text { zinc (II) chloride, tin (IV) } \\
\text { chloride, thiourea. }\end{array}$ & $\begin{array}{l}\text { - XRD studies: The preferential peaks were (112), } \\
\text { (220) and (312) planes [81]. } \\
\text { - SEM studies: uniform surface. } \\
\text { - Optical properties: band gap of } 1.5 \mathrm{eV} \text {. } \\
\text { - Electrical properties: p-type conductivity, } \\
\text { resistivity }\left(0.014 \Omega \text {-cm), mobility }\left(5.4 \mathrm{~cm}^{2} \mathrm{~V}^{-1} \mathrm{~s}^{-}\right.\right. \\
\left.{ }^{1}\right) \text { at room temperature. }\end{array}$ \\
\hline
\end{tabular}




\begin{tabular}{|c|c|c|}
\hline $\mathrm{Cu}_{2} \mathrm{ZnSnS}_{4}$ & $\begin{array}{l}\text { - } \mathrm{Cu}_{2} \mathrm{ZnSnS}_{4} \text { films were annealed } \\
\text { in air under various temperatures } \\
\left(300 \text { to } 350{ }^{\circ} \mathrm{C}\right) \text {. }\end{array}$ & $\begin{array}{l}\text { - XRD studies: formation of kesterite phase [82]. } \\
\text { - Optical properties: Small band gap values (1.5 } \\
\text { to } 1.63 \mathrm{eV}) \text {. } \\
\text { - Electrical properties: electrical resistivity values } \\
(0.1 \text { to } 0.15 \Omega . \mathrm{cm}) \text {. }\end{array}$ \\
\hline $\mathrm{CdS}$ & $\begin{array}{l}\text { - The growth of CdS films on } \\
\text { glass substrate from solution of } \\
\text { cadmium acetate, 2- } \\
\text { methoxyethanol and } \\
\text { polyethylene glycol. }\end{array}$ & $\begin{array}{l}\text { - XRD studies: hexagonal structure with (002) } \\
\text { orientation and the crystallite sizes (5.5 to } 6.8 \\
\text { nm). } \\
\text { - SEM studies: bigger grain and densely packed } \\
\text { grains [83]. } \\
\text { - Optical properties: Band gap values (2.18 to } 2.4 \\
\text { eV). }\end{array}$ \\
\hline $\mathrm{FeS}_{2}$ & 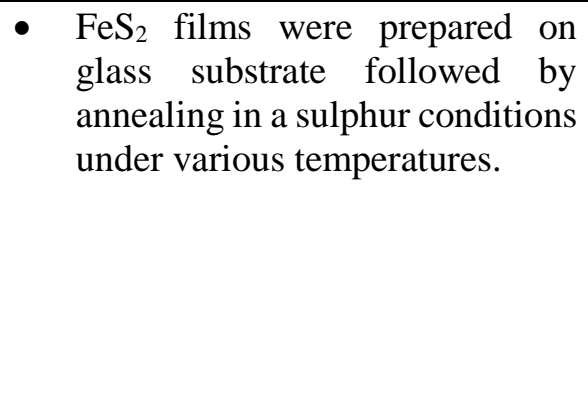 & $\begin{array}{l}\text { - SEM studies: there are some cracks and voids } \\
\text { could be detected [84]. } \\
\text { - XRD studies: crystallinity was improved with } \\
\text { increasing of the sulfurization temperature. } \\
\text { - Optical properties: band gap was increased at } \\
\text { lower temperature. } \\
\text { - Electrical properties: lower resistivity value and } \\
\text { higher Hall mobility, for the films prepared in } \\
\text { lower temperature. }\end{array}$ \\
\hline $\mathrm{CuInSe}_{2}$ & $\begin{array}{l}\text { - } \mathrm{Cu}\left(\mathrm{NO}_{3}\right)_{2}, \mathrm{InCl}_{3} \text { and ethyl } \\
\text { cellulose were used as starting } \\
\text { materials to produce } \mathrm{CuInSe}_{2} \\
\text { films. }\end{array}$ & $\begin{array}{l}\text { - } \text { SEM studies: uniform surface with bigger grain } \\
\text { size [85]. } \\
\text { - } \quad \text { EDAX studies: near stoichiometric. } \\
\text { - XRD studies: } \mathrm{CuInSe} \mathrm{Se}_{2} \text { films could be produced } \\
\text { with increasing selenization temperature. }\end{array}$ \\
\hline $\mathrm{CdS}, \mathrm{PbS}$ & $\begin{array}{l}\text { - } \mathrm{PbS} \text { and } \mathrm{CdS} \text { films were } \\
\text { produced from methanolic } \\
\text { metal-thiourea complex. }\end{array}$ & $\begin{array}{l}\text { - XRD studies: pure cubic structure was observed } \\
\text { [86]. } \\
\text { - SEM studies: smooth surface and homogeneous. } \\
\text { - Optical properties: Band gap of } \mathrm{PbS} \text { and } \mathrm{CdS} \\
\text { was } 1.65 \text {, and } 2.5 \mathrm{eV} \text {, respectively. } \\
\text { - Electrical properties: p-type with electrical } \\
\text { conductivity }(0.8 \mathrm{~S} / \mathrm{cm}) \text { in PbS films. }\end{array}$ \\
\hline $\mathrm{CuInS}_{2}$ & $\begin{array}{l}\text { - Copper acetate monohydrate and } \\
\text { indium acetate were used to } \\
\text { synthesis CuInS }{ }_{2} \text { films on glass } \\
\text { substrate. }\end{array}$ & $\begin{array}{l}\text { - SEM studies: Surface roughness was } 19.1 \mathrm{~nm} \\
\text { [87]. } \\
\text { - XRD studies: chalcopyrite structure was found. } \\
\text { - Raman spectra: Pure phase without a secondary } \\
\text { structure such as InS and CuS. }\end{array}$ \\
\hline $\mathrm{CuSe}$ & $\begin{array}{l}\text { - CuSe films were deposited on } \\
\text { glass substrate. }\end{array}$ & $\begin{array}{l}\text { - XRD studies: polycrystalline in nature [88]. } \\
\text { - } \quad \text { SEM studies: uniform surface without pores. } \\
\text { - } \quad \text { EDAX studies: the presence of copper and } \\
\text { selenide in films. }\end{array}$ \\
\hline
\end{tabular}




\begin{tabular}{|l|l|l|l|}
\hline & & $\bullet$ Optical properties: bandgap was $2.9 \mathrm{eV}$. \\
\hline $\mathrm{CuInSe}_{2}$ & $\bullet \begin{array}{l}\text { CuInSe } \\
\text { two-step spilms were produced via } \\
\text { materials such as copper and } \\
\text { indium naphthenates). }\end{array}$ & $\bullet \begin{array}{l}\text { Photoluminescence studies: two peaks could be } \\
\text { detected }(0.85 \text { and } 1.05 \mathrm{eV}) \text { [89]. }\end{array}$ \\
\hline
\end{tabular}

\section{CONCLUSION}

In this work, preparation and characterization of various types of thin films by using the spin coating method were reported. The physical characteristics were studied through X-ray diffraction, scanning electron microscopy, atomic force microscopy, energy-dispersive X-ray spectroscopy, and UV-visible spectrophotometer technique. Bandgap energy could be determined from the absorption measurement. XRD patterns confirmed that the average grain size is in the nanometer scale. The obtained films could be used for photovoltaic applications due to the appropriate bandgap value.

\section{ACKNOWLEDGEMENT}

INTI International University is gratefully acknowledged for the financial support of this work.

\section{REFERENCES}

1. I. Algimantas, I. Remigijus, and A. Ingrida, Materials, 14: 3810. (2021).

2. K. Noraini, K. Anuar, S.M. Ho, and N. Saravanan, Arab. J. Chem. 3: 243-249, (2010).

3. A. Murugan, V. Siva, S. Abdul, and B. Sultan, J. Alloys Compd. 856: 158055. (2021).

4. A. Kassim, S.M. Ho, S. Atan, W.T. Tan, and K. Zulkefly, Bull. Chem. Soc. Ethiop. 24: 259-266, (2010).

5. A. Adeniji, T. Fowodu, O. Kola, and T. Talabi, Int. J. Thin Films Sci. Technol. 10: 7-11, (2021).

6. W.T. Tan, K. Anuar, S.M. Ho, and N. Saravanan, Macedonian J. Chem. Chem. Eng. 29: 97-103, (2010).

7. S. Siouane, A. Kabir, C. Sedrati, and G. Schmerber, Solid State Sci. 121: 106735. (2021) .

8. A. Hasan, Z. Khan, R. Marnadu, M. Ashraf, M. Shkir, and A. Umar, J. King Saud Univ. Sci. 33(8), 101638. (2021) .

9. K. Ç. Demir. Sci. Semicond. Process. 123: 105553. (2021).

10. K. Anuar, K. Noraini, S.M. Ho, A. Abdul, and N. Saravanan, Dig. J. Nanomater. Biostruct. 5: $975-980$ (2010).

11. A. Imran, S. Mohd, A. Khan, M. Ahmed, and A. Anees, Optik, 167460. (2021).

12. H. Ali, M. Raoof, and N. Ahmed, J. Phys. Conf. Ser. 1963, (2021).

13. S.Y. Gwee, S.M. Ho, A. Kassim, and W.T. Tan, Pac. J. Sci. Technol. 10: 801-805 (2009).

14. S. Atan, S.M. Ho, K. Anuar, and W. Tan, Eur. J. Appl. Sci. 3: 113-116, (2011).

15. O. Kola, A. Sheu, T. Alabi, and O. Fowodu, Int. J. Thin Films Sci. Technol. 10: 117-120, (2021).

16. P. Bagwade, C. Lokhande, B. Ubale, M. Patil, and D. Malavekar, Solid State Sci. 119, 106693. (2021).

17. R. Mikko, M. Miika, R. Jyrki, and H. Timo, Dalton Trans. 50: 13264-13275.(2021).

18. S. Ida, K. Ye, M. Xu, M. James, and Y. Li, Adv. Funct. Mater. 2105563. (2021).

19. A. Jinan, A. Amer, and M. Wasan, Key Eng. Mater. 882: 155-164, (2021).

20. C. Loo, and D. Sabar, $20077^{\text {th }}$ IEEE Conference on Nanotechnology, 930-933. (2007).

21. J. Haron, S.M. Ho, A. Kassim, W. Tan, and A. Dzulkefly, Jurnal Kimia, 4: 1-6, (2010).

22. J. Meena, M. Sreedhar, and P. Seenuvasakumaran, J. Mater. Sci. Mater. Electron. 32: 6855-6865, (2021).

23. M. Boumerzoug, and L.H. Dao, J. Mater. Sci. Mater. Electron. 1: 123-128, (1990).

24. S. Atan, W. Tan, S.M. Ho, K. Anuar, and N. Saravanan, Indian J. Eng. Mater. Sci. 17: 295-298, (2010).

25. W. Sarah, and N. Lea, Joule, 4: 524-538, (2020).

26. N. Niklas, H. Freund, and F. Stavale, New J. Phys. 14: 033006. (2021).

27. L. Chen, J. Dash, P. Su, M. Lu, and G. Wang, Appl. Surf. Sci. 288: 458-465, (2014).

28. S. Seo, J. Nichols, H. Gruenewald, Rev Sci Instrum, 84: 043902, (2013).

29. https://www.semanticscholar.org/paper/Thin-Film-Deposition-Techniques-PhysicalMethods/fb873238a07b427d88649f3c829d35155c30f62f.

30. W. Tan, S.M. Ho, K. Anuar, and N. Saravanan, Eur. J. Sci. Res. 66: 592-599, (2011).

31. E. Hatam, and N. Ghobadi, Mater. Sci. Semicond. Process. 43: 177-181, (2016).

32. J. Mohd, K. Anuar, Y. Mohd, S.M. Ho, W. Tan, and A. Abdul, Kuwait J. Sci. Eng. 37: 63-73, (2010).

33. M. Shanthi, N. Saravanan, S.M. Ho, W. Tan, and K. Anuar, Kathmandu Univ. J. Sci. Eng. Technol. 6: 126-132, (2010).

34. T. Khan, F. Mehmood, A. Mahmood, A. Shah, Q. Raza, and A. Iqbal, Thin Solid Films, 519: 5971-5977, (2011).

35. K. Lim, K. Anuar, S.M. Ho, and N. Saravanan, Sultan Qaboos Univ. J. Sci. 16: 24-33, (2011).

36. Z. Kuang, S. Atan, S.M. Ho, K. Anuar, N. Saravanan, and T. Tan, Solid State Sci. Technol. 17: 226-237, (2009). 
37. S.M. Ho, Asian J. Chem. 2:, 3851-3853, (2015).

38. S.M. Ho, K. Anuar, and T. Tan, Univ. J. Chem. 1: 170-174, (2013).

39. T. Tan, S.M. Ho, K. Anuar, and N. Saravanan, Bangladesh J. Sci. Ind. Res. 46: 243-246, (2011).

40. A. Ates, M. Saglam, and B. Guzeldir, Acta Phys. Pol. A, 121: 33-35, (2012).

41. S.Y. Gwee, N. Saravanan, S.M. Ho, M. Atan, K. Anuar, W. Tan, and D. Abdullah, Indo. J. Chem. 10: 8-11, (2010).

42. J. Puiso, S. Lindroos, S. Tamulevicius, V. Snitka, and M. Leskela, Solid State Phenom. 94: 261-264, (2003).

43. H. Dong, A. Jung, N. Kwun, S. Kwan, and S. Young, Nanoscale Res. Lett. 7: 1-7, (2012).

44. W. Tan, S.M. Ho, and A. Kassim, J. Basic Appl. Sci. Res. 3: 353-357, (2013) [44].

45. K. Benyahia, M. Aida, and A. Benhaya, J. Semicond. 36: 103001, (2015).

46. Y. Loh, S.M. Ho, K. Anuar, and N. Saravanan, Silpakorn Univ. Sci. Technol. J. 4: 36-42, (2010).

47. Joo, S. Han, A. Shaikh, M. Pathan, R. Mane, and S. Kale, Appl. Surf. Sci. 253: 4335-4337, (2007).

48. K. Rupali, R. Sachin, P. Amit, R. Waykar, J. Ashok, and J. Vijaya, Energy Proc. 110: 188-195, (2017).

49. R. Tang, Z. Wang, W. Li, L. Feng, J. Zhang, L. Wu, and B. Li, Sol. Energy Mater. Sol. Cells, 121: 92-978, (2014).

50. C. Yan, H. Guo, J. Wen, Z. Zhang, and K. He, Surf. Sci. 621: 104-108, (2014).

51. H. Salim, A. Nor, M. Madugu, I. Olajide, and M. Imyhamy, Energies, 8: 10883-10903, (2015).

52. H. Hany, M. Mona, and S. Mohamed, IOSR J. Appl. Phys. 7: 19-22, (2015).

53. M. Shaban, and M. El-Sayed, Mater. Sci. Semicond. Process. 39: 136-147 (2015).

54. M. G. Buonomenna; Smart Composite Coatings and Membranes: Woodhead Publishing, Cambridge, UK, pp. 371-419 (2016).

55. R. Smith, P. Cor, and I. Hiroshi, Supercrit. Fluid Sci. Technol. 4: 175-273 (2013).

56. N. Fourati, N. Blel, Y. Lattach, N. Ktari, and C. Zerrouki; Ref. Mod. in Mater. Sci. Mater. Eng. (2016).

57. N. T. Nguyen; Fabrication technologies, In "Micromixers (2 $\left.{ }^{\text {nd }}\right)$ : William Andrew, Norwich, US. 113-161, (2012).

58. T. Kerdcharoen, and K. Wongchoosuk; Carbon nanotube and metal oxide hybrid materials for gas sensing. In Semiconductor gas sensor. Woodhead Publishing, Cambridge, UK, pp. 386-407, (2013).

59. K. Surekha, and S. Sureshbabu; Self-cleaning glass. In: anti-abrasive nanotechnologies: current and future applications, Woodhead, Cambridge, UK. pp 81-103, (2015).

60. A. S. H. Makhlouf. In:Nanocoatings and ultra-thin films. Woodhead Publishing, Cambridge, UK, Pp 3-23 (2011).

61. P. Sevvanthi, A. Claude, C. Jayanthi, and A. Poiyamozhi, Adv. Appl. Sci. Res. 3: 3573-3580, (2012).

62. S. Marek, and L. Dobrzanski, J. Achiev. Mater. Manuf. Eng. 52: 7-14, (2012).

63. K. Verma, U. Hashim, P. Deo, M. Abubaker, A. Ibraheam, and Y. Douri, Int. J. Electrochem. Sci. 10: $9863-$ 9876, (2015).

64. A. A. Odeh, Y. Douri, M. Ameri, A. Bouhemadou, Indian J. Phys. 92: 695-703. (2018).

65. M. Kallol, S. Kumar, and B. Sudip, Sol. Energy Mater. Sol. Cells, 161: 157-161, (2017).

66. S. Yasar, S. Kahraman, S. Cetinkaya, and I. Bilican, J. Alloys Compd. 618: 217-221, (2015).

67. H. Dahman, and E. Mir, J. Mater. Sci. Mater. Electron. 26: 6032-6039, (2015).

68. H. Jun, Y. Zhou, Y. Tian, Z. Huang, and X. Wang, Front. Optoelectron. 7: 37-45, (2014).

69. D. Dissanayake, and P. Samarasekara, J. Sci. Univ. Kelaniya Sri Lanka, 10: 13-20, (2015).

70. A.M. Thambidurai, N. Murugan, S. Agilan, and N. Muthukumarasamy, Chalcogen. Lett. 6: 171-179, (2009).

71. Lahewil, U. Hashim, M. Ahmed, and Y. Douri, Proc. Eng. 53: 217-224, (2013).

72. K. Nitin, P. Purohit, and Y. Goswami, Phys. E: Low Dimens. Syst. Nanostruct. 83: 333-338, (2016).

73. A. Sabitha, and H. Joe, Mater. Today Proc. 2: 1046-1050, (2015).

74. A.Tarun, M. Zaman, K. Dehury, and P. Rajaram, AIP Conf. Proc. 1953, 100066, (2018).

75. Mukherjee, and P. Mitra, J. Phys. Sci. 16: 171-175, (2012).

76. A.P. Samarasekara, B. Basnayaka, and D. Sunil, Condens. Matter Mater. Sci. (2017).

77. S. Takahiro, and S. Ando, International Semiconductor Conference. IEEE. 81-84, (2015).

78. B.Sunil, H. Joshi, P. Tailor, and P. Deshpande, Mater. Res. Express, 4: 076402. (2017).

79. A.Raut, C. Pawar, B. Patil, and V. Karande, AIP Conf. Proc. 2, 1-6. (2010).

80. S. Kahraman, S. Yasar, I. Bilican, and S. Cetinkaya, J. Philos. Mag. 94: 94: 3149-3161. (2014).

81. S.Swami, A. Kumar, and V. Dutta, Energy Proc. 33: 198-202, (2013).

82. Ziti, H. Bouchaib, H. Labrim, F. Salah, and A. Ridah, Superlattices Microstruct. 127, 191-200. (2019).

83. Olopade, M. Awobode, O. Awe, and T. Imalerio, Int. J. Res. Rev. Appl. Sci. 15: 120-124, (2013).

84. A.Thanh, N. Nguyen, P. Viet, H. Kim, and C. Park, Korean J. Chem. Eng. 35: 1525-1531 (2018). 
85. N. Yao, X. Zhu, J. Ma, Y. Liang, and J. Jiang, 8th International Conference on thin-film Physics and applications. 9068, 906806 (2013).

86. P. Jayesh, M. Frej, A. Ajji, and D. Tiwari, Appl. Phys. A, 117: 1791-1799 (2014).

87. S. Lee, and B. Park, Thin Solid Films, 516: 3862-3864 (2008).

88. Guzeldir, and M. Saglam, Spectrochim. Acta A. Mol. Biomol. Spectrosc, 150: 111-119, (2015).

89. S. Merdes, K. Atsuki, H. Zahia, S. Mutsumi, N. Hisayuki, and S. Ando, Jpn. J. Appl. Phys. (2008). 